\title{
sciendo
}

DOI: 10.2478/orga-2020-0002

\section{Environmental Reporting and Speed of Adjustment to Target Leverage: Evidence from a Dynamic Regime Switching Model}

\author{
Hafezali Iqbal HUSSAIN ${ }^{1}$, Sebastian KOT², Hassanudin \\ Mohd Thas THAKER ${ }^{3}$, Jason J TURNER ${ }^{4}$
}

\begin{abstract}
${ }^{1}$ Taylor's Business School, Taylor's University Lakeside Campus, 1 Jalan Taylors, Subang Jaya 47500, Malaysia, and Visiting Professor, University of Economics and Human Sciences in Warsaw, Poland, hafezali.iqbalhussain@ taylors.edu.my (corresponding author)

${ }^{2}$ Czestochowa University of Technology, The Management Faculty, Armii Krajowej 19B,42-201 Czestochowa, Poland and Faculty of Economic and Management Sciences, North-West University, Vaal Triangle Campus, PO Box 1174 Vanderbijlpark 1900, South Africa, sebacat@zim.pcz.czest.pl

${ }^{3}$ Sunway University, Sunway University Business School, Department of Economics and Finance, Bandar Sunway, 47500 Petaling Jaya, Selangor, Malaysia, hassanudint@sunway.edu.my

${ }^{4}$ Asia Pacific University of Technology \& Innovation, Graduate Schools of Business, Jalan Teknologi 5, Taman Teknologi Malaysia, 57000 Kuala Lumpur, Malaysia, jasonjamesturner@staffemail.apu.edu.my
\end{abstract}

Background and Purpose: This study investigates the impact of environmental reporting on speed of adjustment and adjustment costs which is evaluated based on the ability of firms to adjust to target leverage level for non-financial firms listed in the Malaysian Stock Exchange (Bursa Malaysia).

Design/Methodologyl Approach: The study selects Malaysian firms based on the contracting and political cost of the economy which is seen as a relationship-based economy. This in turn influences a firm's ability to obtain external financing and thus has an important impact on capital structure decisions. In addition, the method employed allows for a direct measure on adjustment cost for firms. The current study utilises a dynamic regime switching model based on the DPF estimator to estimate rate of adjustment to optimal target levels based on the distinction of environmental reporting of public listed firms. The approach allows statistical inferences to control for potential serial correlation, endogeneity and heterogeneity concerns which accounts for firm specific characteristics.

Results: The empirical findings suggest voluntary disclosure on environmental reporting increases a firm's ability to access external financing at a cheaper cost as evidenced by a more rapid rate of adjustment. The findings are consistent across differing endogenous and exogenous factors indicating that these firms tend to face lower adjustment costs.

Conclusion: The current study provides a direct measure on the ability of firms to adjust to target levels via security issues and repurchases in the capital markets. This in turn is a reflection of perceived riskiness and value from the investors' point of view in an emerging market. Prior studies have focused on environmental reporting and equity risk premiums and have not evaluated the direct impact on firm value given that the trade-off theory of capital structure predicts that firm value is maximised at target i.e. optimal levels of leverage. This study addresses the current gap in the literature by evaluating the impact on firms' value, based on the adjustment cost.

Keywords: Environmental reporting, capital structure, speed of adjustment, DPF estimator, dynamic panel data

Received: October 29, 2019; revised: January 13, 2020; accepted: January 30, 2020 


\section{Introduction}

The study aims to understand the practice of voluntary disclosure of environmental information by publicly listed firms in a developing country, through the measurement of the speed of adjustment to optimal leverage levels ${ }^{1}$ which is assumed to be the target levels of firms given that managers are working to maximise firm value. The issue of environmental reporting and the broader subject of corporate social responsibility has received attention in the academic and practitioner literature in recent times around disclosing information on waste management, programs for recycling as well as the implementation of environmental controls (Ali et al., 2017; Cho et al., 2015). Disclosure of such information attracts investors' attention given its voluntary nature which is deemed by some to be costly (Michelon et al., 2015). These costs arise mainly from compiling expenditure, given that the nature of information being disclosed is not readily available in accounting systems or the financial reporting infrastructure of most companies (Fernandes et al., 2018; Khlif et al., 2015). By providing commentary around the rationale for disclosing non-mandated information, examining the rate of adjustment to target leverage (i.e. adjustment costs which is implied through the speed of adjustment to optimal levels), the research will be addressing an identified gap in the environmental reporting as well as capital structure literature. Furthermore, the research will be able to provide further insight into the role of relative adjustment costs and its relationship with voluntary disclosure of environmental information in a country where transaction costs are known to be high (Lemma and Negash, 2014; Öztekin, 2015; Öztekin and Flannery, 2012; Ting, 2016).

The rate of adjustment is considered dependent on the ability of firms to adjust to target levels which are reliant on costs of financing i.e. costs incurred to raise capital (including indirect costs) as well as adjustment costs. Disclosure of environmental information which is voluntary in nature may affect a firm's speed of adjustment which is based on the perceived riskiness measure of investors and thus affects adjustment costs (Plumlee et al., 2015). Arguably, firms which are deemed to be socially responsible tend to have the ability to raise equity at cheaper costs i.e. demand a price premium (Hussain et al., 2019). A contrasting trend is observed for firms below target levels where debt issuers with disclosures are seen to adjust at slower rates. It is considered likely that firms with environmental reporting tend to maintain lower levels of leverage given that the voluntary disclosure acts as an additional measure of assessing financial risk which points towards market-imposed discipline (Andrikopoulos et al., 2014; Brammer and Pavelin, 2008). Investigating this area of research and in the context of a developing country like
Malaysia, is particularly interesting given they have a relationship-based economy where contracting and political costs heavily influence financing behaviour (Ebrahim et al., 2014; Hussain et al., 2018; Rajan and Zingales, 1998).

To address the aims of this research the paper is structured as follows: Section 2 provides a brief review of the relevant literature to contextualise the study whilst section 3 provides a description of the data and sample selection process. The empirical model and methodological approach are presented in section 4 . Section 5 reports and discusses the results. Section 6 provides concluding remarks on the implications of the findings which improves understanding of the link between voluntary environmental disclosure and the impact on adjustment costs for firms from the perspective of an emerging capital market.

\section{Literature Review}

Studies examining the importance of social financing disclosures have been gaining traction in the literature and stems from the need to emphasize sustainable development. The motivation behind these studies are based on the scarcity of environmental resources, hence the utilisation of these scarce resources needs to be accounted for (Martin-Ortega et al., 2011). Whilst the willingness of firms to disclose the utilisation of these scarce resources has seen some increases over the years (Jose and Lee, 2007), voluntary disclosure is still an area which lacks academic discussion (Kuo and Chen, 2013; Zhang et al., 2016).

The nature of environmental disclosure can be segregated into coercive versus voluntary disclosure (Doshi et al., 2013; Lewis et al., 2014). Coercive disclosure stems from governmental regulations which is mandatory in nature whilst voluntary disclosure is driven by demand from stakeholders as well as internal firm characteristics. Findings in the literature indicate that pressure from stakeholders can lead to increased voluntary disclosure (Lewis et al., 2014). These stakeholders range from environmentally conscious investors, nongovernmental organisations as well as customers (Clarkson et al., 2008). However, these pressures are mainly present in developed countries where international firms tend to attract the attention of stakeholder groups who are well-organised (Aragón-Correa et al., 2016). The scenario in developing countries tends to be markedly different given there is limited interaction with these demanding stakeholders (Md Zaini et al., 2018). Better understanding of the impact of voluntary environmental disclosures on adjustment costs in the context of a developing country and its influence on firm value is therefore important to gain further holistic insight into the value of voluntary environmental reporting.

1 For empirical purposes, both terms (optimal and target leverage levels) are used interchangeably in the current study 


\subsection{Motivations for Voluntary Environmental Disclosures}

There could be a number of plausible motivations behind a firms voluntary environmental reporting but the most discussed is derived from the concept of organisational legitimacy (Deegan, 2002). The legitimacy view provides four reasons for disclosure. The first is based on the need for the firm to provide information to the 'relevant publics' in order to reduce the legitimacy gap arising from expected impact on firm performance due to changes in environmental concerns (Qian and Schaltegger, 2017). The second explanation is based on the need to change perceptions which are not reflected in actual behaviour and where a firm may in fact be engaged in undesirable practices yet want to promote the image of an environmentally friendly workplace (Alrazi et al., 2015).

The third arises from the intention to detract attention away from public concerns via the use of emotive imagery such as disclosing information on a particular recycling program implemented in an attempt to deflect attention away from pollution caused by production (Fisher et al., 2017). The final justification under organisational legitimacy arises from wanting to alter expectations of stakeholders which may be unrealistic (Bond et al., 2016). These however are not the only reasons, when considering the issue of voluntary environmental reporting, there are also other systematic factors which are related to the firms characteristics as well as the external environment in which firms operate (Braam et al., 2016).

The view of information asymmetry between insiders and outsiders argues that voluntary disclosure would tend to have an influence on the transparency as well as the accountability of the firm (Birkey et al., 2016). Thus, the motivation behind such voluntary disclosure would be determined by the potential benefit arising from a reduction in information asymmetry versus the costs that would hinder voluntary disclosure (Arena et al., 2015). Emerging countries with unique capital market would tend to have differing reasons for such voluntary disclosures (Belal et al., 2013). The literature documents that governance in developing markets are weaker given that political and social environment leads to poorer enforcement as well as potential collusion between state and the organisation (Song et al., 2015).

In addition, the ownership and control of listed firms in developing countries tend to be highly concentrated relative to developed markets which are inclined to have greater dispersion of ownership (Lemmon and Lins, 2003). The trend observed in these capital markets has seen the expropriation of wealth at the expense of minority shareholders due to weak governance structures (Claessens and Yortoglu, 2013; La Porta et al., 2000). Such concentration of ownership has also been associated with lower levels of voluntary disclosures (Akhtaruddin et al., 2009). Further- more, the public awareness of social and environmental issues as well as institutional and regulatory enforcement, tend to be lower in developing countries which reduces the pressure for providing such voluntary disclosures (Xiao et al., 2005).

\subsection{Adjustment to Target Capital Structure and Firm Value}

The irrelevance hypothesis proposes that firm value is independent of capital structure in perfect capital markets (Modigliani and Miller, 1958). In the presence of market imperfections, firms' have the incentive to issue debt given the benefit arising from tax deductibility of interest payments (Modigliani ad Miller, 1963). Debt issues in imperfect markets however bring about further costs which are weighed against the potential benefits of debt leading to a situation where managers are constantly trading-off to reach an optimal level where firm value is maximised ( Ju et al., 2005; Shyam-Sunder and Myers, 1999). This gives rise to the dynamic view of capital structure where firms are constantly attempting to reach optimal leverage levels where the marginal benefits arising from further issues are offset by the marginal costs of increasing leverage levels (Abel, 2018; Hackbarth, Miao and Morellec, 2006).

The trade-off theory explanation of capital structure is therefore based on the ability of firms to adjust to target levels based on the cost of adjustment (Öztekin, 2015; Zhou et al., 2016). As a result, managers are taking into account the cost of adjustment arising from market imperfections which is weighed against the potential benefit of operating at, or close to optimal levels. Deviation from target levels tends to be significant even in the presence of low adjustment costs, such as firms operating in developed financial markets which predicts speed of adjustment which is significantly greater than zero (Chang et al., 2015). In the presence of adjustment costs, it is found that firms exhibit large deviations from target levels with longer halflife (Öztekin, 2015). Firms based in countries with weaker legal and financial market institutions tend to face greater adjustment costs and hence would deviate longer from target levels and lower rates of adjustment (Öztekin and Flannery, 2012).

The presence of optimal or target levels is further validated by managers in developed and developing countries pursuit of target debt ratios (Brounen et al., 2006; Nor et al., 2012). The empirical evidence illustrates that exogenous factors such as macro-economic shocks which influence firms' riskiness as well as variance in cash flows tend to have an impact on speed of adjustment (Cook and Tang, 2010). The risk factor is moderated by information of the capital market with firms operating in markets where there are greater levels of information asymmetry tending to face greater transaction costs (An et al., 2015). 
The level of disclosure is also found to be contentious in its impact on capital structure. The rate of adjustment is argued to depend on a firms' endogenous characteristics which leads to heterogeneity across firms (Faulkender et al., 2012). Theoretically, increased voluntary reporting would lead to greater levels of transparency which provides firms with reduced costs of raising capital. Hence firms would be able to adjust at more rapid rates (Yang et al., 2018). The literature however provides conflicting information where there has been evidence showing that voluntary environmental reporting is associated with lower leverage levels (Ahmad et al., 2003). The rationale behind increased disclosure leading to lower levels of leverage is based on the argument that firms with lower levels of leverage are engaging in greater levels of voluntary environmental disclosure as a precautionary measure to assess financial risks. In addition, there have also been arguments indicating that additional voluntary disclosure has no impact on the cost of capital and thus would not directly affect adjustment costs (Bertomeu et al., 2011).

The debate in the current literature indicates that there is a lack of certainty around the impact of voluntary environmental disclosure on a firm's ability to raise capital especially in the context of developing markets. Previous studies neglect the impact of such voluntary disclosures on firm value, rather focusing on risk premiums. This study aims to close this identified gap by measuring the rate of adjustment whilst accounting for heterogeneity (discloser versus non-discloser) which provides an indication of firm value given that firm value is maximised when operating at optimal leverage levels. The study will examine the adjustment costs arising from information asymmetry in the context of the Malaysian capital market given its institutional and financial market characteristics based on a firms' heterogeneity arising from voluntary environmental disclosure.

\section{Methodology}

The classical approach found in the empirical literature to estimate speed of adjustment utilises the lagged dependent based on a partial adjustment model which can be expressed as follows (Öztekin and Flannery, 2012):

$$
\text { Leverage }_{i t}-\text { Leverage }_{i t-1}=\lambda\left(\text { Leverage }_{i t}^{*}-\text { Leverag }_{i t-1}\right)+\varepsilon_{i t}
$$

The speed of adjustment $(\lambda)$ in this approach is given by the distance of the lagged leverage $\left(\mathrm{Debt}_{\mathrm{it}-1}\right)$ and the optimal debt ratio which is time variant $\left(\right.$ Leverage $\left._{\text {it }}^{*}\right)$. In the event that the coefficient $(\lambda)=0$, firms do not adjust to optimal levels (leverage changes are random). However, if $(\lambda)=1$, firms are able to fully and immediately adjust to target levels, hence eliminating deviation from optimal ratios. At the optimal point (which in the practical sense would be the ultimate target level of leverage for managers who are assumed to be working to maximise shareholders' wealth), firm value is maximised (Warr et al., 2012). The empirical approach would call for rearranging the equation (1) whilst controlling for firm specific characteristics which are related to costs and benefits of debt and equity as well as accounting for unobservable components. Regressing the current leverage against the lagged dependent variable captures the rate of adjustment which eliminates the need to estimate a target leverage level. Thus, the model can be expressed linearly as follows (Öztekin, 2015):

$$
\text { Leverage }_{i t}=(1-\lambda) \text { Leverage }_{i t-1}+\lambda \beta X_{i t}+\eta_{i}+\eta_{t}+\varepsilon_{i t}
$$

where $\mathrm{X} \_$it is a vector of determinants which are firm specific, $\beta$ is the coefficient vector which includes an intercept, $\eta_{-} i$ is fixed effects for firms whilst $\eta_{-} t$ is fixed effects for time. Thus if $\alpha=1-\lambda$ and $\gamma=\lambda \beta$, equation (2) can be rewritten to represent a testable empirical model as follows:

$$
\text { Leverage }_{i t}=\text { aleverage }_{i t-1}+\gamma X_{i t}+\eta_{i}+\eta_{t}+\varepsilon_{i t}
$$

The expression in equation (3) assumes that the speed of adjustment as well as firm specific factors are time-invariant and constant across groups. However, given that the current study is focusing on the impact of voluntary disclosure of firms on the speed of adjustment, heterogeneity is introduced into the model. The model in equation (3) is therefore extended in order to account for time-variation as well as inter-group variation in estimating the $\lambda$ parameter to measure the speed of adjustment. This can be achieved by utilising a regime-switching partial adjustment model which allows the variation of both factors (speed of adjustment as well as the importance of firm specific characteristics) over the two regimes (Kareem and Mijbas, 2019). Both regimes can be defined based on disclosing or non-disclosing firms and the models for the differing regimes are as follows:

$$
\begin{aligned}
& \text { Leverage }_{i t}^{(1)}=\alpha_{1} \text { Leverage }_{i t-1}^{(1)}+\gamma_{1} X_{i t}^{(1)}+\eta_{1 i}+\eta_{1 t}+\varepsilon_{i t}^{(1)} \\
& \text { Leverage }_{i t}^{(2)}=\alpha_{2} \text { Leverage }_{i t-1}^{(2)}+\gamma_{1} X_{i t}^{(2)}+\eta_{2 i}+\eta_{2 t}+\varepsilon_{i t}^{(2)}
\end{aligned}
$$

Both models can be rewritten in a single model as follows:

$$
\begin{aligned}
& \text { Leverage }_{i t}=R D_{1}\left(\alpha_{1} \text { Leverage }_{i t-1}+\gamma_{1} X_{i t}+\eta_{i}+\eta_{t}+\varepsilon_{i t}\right) \\
& +R D_{2}\left(\alpha_{2} \text { Leverage }_{i t-1}+\gamma_{2} X_{i t}+\eta_{i}+\eta_{t}+\varepsilon_{i t}\right)
\end{aligned}
$$


where $\mathrm{RD}_{1}$ and $\mathrm{RD}_{2}$ are two dummies which capture the different regimes and thus are equal to 1 if firm $\mathrm{i}$ is in a particular regime at time $t$, and zero otherwise. Therefore, the extended model in equation (6) provides a direct comparison between speed of adjustment to target levels for the differing regimes (in this case firms with and without voluntary environmental disclosures). The equation can be transformed into a simpler form to improve numerical stability as well as provide simplification in testing of statistical significance and is thus implemented in the following form for the empirical analysis in the current study as follows (Halling et al., 2016):

$$
\begin{aligned}
& \text { Leverage }_{i t}=\alpha_{1} \text { Leverage }_{i t-1}+\left(\alpha_{2}-\alpha_{1}\right) \text { Leverage }_{i t-1} R D_{2} \\
& +\gamma_{2} X_{i t}+\left(\gamma_{2}-\gamma_{1}\right) X_{i t} R D_{2}+\eta_{i}+\eta_{t}+\varepsilon_{i t}
\end{aligned}
$$

The model expressed in equation (7) is dynamic in nature which is time-variant and thus can be referred to as a partial adjustment model based on regime switching. The research notes the argument in the literature that speed of adjustment can be biased in traditional estimation methods due to heterogeneity arising from firm specific differences (Elsas and Florysiak, 2011; Faulkender et al., 2012). The bias arises from the nature of unbalanced panel data used in the current study, heterogeneity which is unobservable, inclusion of lagged leverage as an independent variable to explain leverage and the measurement of the dependent variable which is also a ratio (Flannery and Hankins, 2013). The biasness is overcome in this research by adopting a Tobit estimator which is doubly censored (restricted to range between 0 and 1 ) and which is referred to as a DPF estimator. The approach allows estimation of results to overcome the issue of mechanical mean reversion as well as the aforementioned biasness as it relies on a latent variable (Elsas and Florysiak, 2015). The estimator is further extended to include firm fixed effects and is robust enough to consider missing observations (Loudermilk, 2007). The model is estimated by assuming that the latent variable, which is unobservable (Leverage ${ }^{+}$it), evolves based on a dynamic model setting and thus can be expressed as follows:

$$
\text { Leverage }_{i t}^{+}=\alpha \text { Leverage }_{i t-1} \gamma X_{i t}+\eta_{i}+\eta_{t}+\varepsilon_{i t}
$$

Based on equation (8), Leverage ${ }_{i t}$ is estimated as the observable dependent variable which is doubly-censored and thus the possible outcomes are expressed as follows:

$$
\text { Leverage }_{i t}=\left\{\begin{array}{c}
0 \text { if } \text { Leverage }_{i t}^{+} \leq 0 \\
\text { Leverage }_{i t}^{+} \text {if } 0<\text { Leverage }_{i t}<1 \\
1 \text { if } \text { Leverage }_{i t}^{+} \geq 1
\end{array}\right.
$$

In the theoretical sense, the latent unobservable var- iable $\left(\right.$ Leverage $^{+}{ }_{\text {if }}$ ) is treated as its debt capacity which can lie outside the range of 0 to 1 (Elsas and Florysiak, 2015). However, in the empirical model replacements are performed in order to correct errors in observed data given that these values are rarely found in reality. The model expressed in equation (8) is based on the assumption that firm fixed effects $\left(\eta_{\mathrm{i}}\right)$ which are the unobserved heterogeneity at firm level can be specified. The heterogeneity at firm level is dependent on the mean value of firm specific characteristics $\mathrm{E}(\mathrm{Xi})$ as well as the leverage level in the initial period of observation (Leverage ${ }_{i 0}$ ) and can be expressed as follows:

$$
\eta_{i}=\alpha_{0}+\alpha_{1} \text { Leverage }_{i 0}+\alpha_{2} E(X i)+\alpha_{i}
$$

where the error term $\left(\alpha_{\mathrm{i}}\right) \sim \mathrm{N}\left(0 \sigma_{\mathrm{a}}^{2}\right)$. In the current study, equation (8) is estimated using a Tobit estimator based on the conditions stipulated in equations (9) and (10) utilising the maximum likelihood estimation method.

\subsection{Data and Variables}

Data is obtained from the Thomson Reuters Datastream $^{3}$ database for Malaysian firms for the years 2014 to 2018. Industry classifications are divided into 10 categories and reported in the Appendix. In addition, financial firms are eliminated from the sample given that their capital structures tend to lead to bias in estimates of speed of adjustment (Hussain et al., 2019; Mallisa and Kusuma, 2017). Missing values are further dropped from the sample. Winsorizing of all variables at the 1st and 99th percentile was conducted to eliminate the effect of outliers (Gorondutse et al., 2017). The refinement and filtering of data leaves a final sample of 698 firms with a total of 2,619 firm-year observations. The variables utilised in this study are based on common regressors identified for studies in capital structure and presented in Table 1.

Both book debt and market debt ratios are utilised as dependent variables given that these variables are interdependent and the consensus in the literature indicates that both are of concern to managers (DeAngelo and Roll, 2015). This study defines environmental disclosures as any specific sentence in the annual report that provides a discussion on an aspect of the natural environment (Ahmad et al., 2003). This is inclusive of any awards won for

2 Datastream is a "global financial and macroeconomic data platform providing data on equities, stock market indices, currencies, company fundamentals, fixed income securities and key economic indicators for 175 countries and 60 markets" (European University Institute, 2019, n/p). It can be accessed via institutional subscription at https://www.thomsonone.com/DirectoryServices/2006-04-01/Web.Public/ Login.aspx?brandname $=$ datastream 
Table 1: Definition of Variables

\begin{tabular}{|l|l|}
\hline Variable & Description \\
\hline Book Leverage (BL) & Total debt scaled by book value of total assets \\
\hline Market Leverage (ML) & Total debt scaled by market value of equity plus book value of debt \\
\hline Firm Size (SIZE) & Natural log of net sales at 2014 prices \\
\hline Profitability (PROF) & Earnings Before Interest and Taxes scaled by total assets \\
\hline Earnings Volatility (VOL) & Standard deviation of EBIT scaled by total assets for the past 3 years \\
\hline Market-to-Book Ratio (MTB) & $\begin{array}{l}\text { Ratio of the book value of total assets less book value of equity plus the market value of } \\
\text { equity to book value of total assets }\end{array}$ \\
\hline Asset Tangibility (TANG) & Net Property, Plant and Equipment scaled by total assets \\
\hline Industry Leverage (INDL) & Median leverage (book or market) of the industry \\
\hline
\end{tabular}

Table 2: Comparison of firm specific characteristics

\begin{tabular}{|l|c|c|c|}
\hline \multicolumn{1}{|c|}{ Variable } & Discloser Firms & Non-Discloser firms & T-values (absolute) \\
\hline BL & 0.1488 & 0.2265 & $3.96^{* * *}$ \\
\hline ML & 0.1836 & 0.2938 & $5.26^{* * *}$ \\
\hline SIZE & 19.9362 & 18.9968 & 1.24 \\
\hline PROF & 0.0634 & 0.0625 & 0.38 \\
\hline VOL & 0.0296 & 0.0625 & $4.82^{* * *}$ \\
\hline MTB & 1.9928 & 2.0184 & 0.63 \\
\hline TANG & 0.3240 & 0.2435 & $3.25^{* * *}$ \\
\hline
\end{tabular}

Notes: $* * *, * *$ and $*$ indicate significance at the $1 \%, 5 \%$ and $10 \%$ level respectively. Source: Author's own

environmental related issues or standards obtained. It was found that 248 firms were classified in the discloser group whilst the balance are categorised as non-disclosers. This indicates that about $38 \%$ of firms in Malaysia have some form of voluntary environmental disclosure in their annual reports for the years 2014 to 2018. Comparison of firm specific characteristics are reported in Table 2 for both groups of companies.

In-line with our expectations derived from the empirical literature, we find that the discloser group tends to have lower levels of leverage. Given that their profitability is higher whilst their tangibility levels do not differ significantly, it is clear that the lower borrowing strategy is not influenced by the usual determinants of capital structure. Furthermore, these companies tend to be larger and thus would, in theory, have larger debt capacity. It does point towards the ability of firms to raise equity at cheaper costs relative to the non-discloser group, indicating that investors tend to attach a lower risk premium as a consequence of greater levels of voluntary disclosure. In order to analyse whether this ultimately translates into increased firm value, the current study investigates the rate of adjustment for these firms to reach optimal levels.

\section{Empirical Results and Discussion}

\subsection{Optimal Leverage Levels}

The current study is aimed at measuring the speed of adjustment based on the dynamic regime switching model. This provides a comparative basis for firms in the discloser and non-discloser groups. In order to ensure that parameters are estimated accurately, initial diagnostics were performed based on the panel unit root test to ensure that all regressors applied were stationary. Thus, the panel unit root test was applied for all variables based on three different approaches (Dickey and Fuller, 1979; Im et al., 2003; Levin et al., 2002). Results for the estimations are reported in Table 3 below.

Based on the estimation results reported in Table 3, it can be observed that all regressors are stationary at I (0) which means that the nulls for unit root are rejected. However, further analysis based on the dynamic regime switching model can be applied to estimate the rate of adjustment to optimal levels. The target leverage regressions are then reported in Table 4 below for book and market leverage whilst controlling for firm specific characteristics. 
Table 3: Unit Root Test for Panel Data

\begin{tabular}{|c|c|c|c|}
\hline Variable & IPS T-Stat & LLC T-Stat & ADF Fischer T-Stat \\
\hline BL & $-16.295^{* * *}$ & $-6.289^{* * *}$ & $85.962^{* * *}$ \\
\hline ML & $-18.256^{* * *}$ & $-8.624^{* * *}$ & $96.258^{* * *}$ \\
\hline SIZE & $-9.258^{* * *}$ & $-4.085^{* * *}$ & $68.962^{* * *}$ \\
\hline PROF & $-15.252^{* * *}$ & $-6.210^{* * *}$ & $69.263^{* * *}$ \\
\hline VOL & $-22.884^{* * *}$ & $-11.925^{* * *}$ & $98.928^{* * *}$ \\
\hline MTB & $-56.951^{* * *}$ & $-22.486^{* * *}$ & $99.622^{* * *}$ \\
\hline TANG & $-28.451^{* * *}$ & $-15.262^{* * *}$ & $126.325^{* * *}$ \\
\hline
\end{tabular}

Notes: ***,** and * indicate significance at the 1\%, 5\% and 10\% level respectively. IPS represent Im, Pesaran and Shin (2003), LLC represent the Levin, Lin \& Chu (2002), ADF represent the Dickey and Fuller (1979) panel unit-root test approach respectively. Source: Author's own

Table 4: Speed of Adjustment to Target Leverage

\begin{tabular}{|l|c|c|}
\hline & BL & ML \\
\hline LEVERAGE $_{(\mathrm{t}-1)}$ & $0.7988^{* * *}$ & $0.8025^{* * *}$ \\
Speed of Adjustment (SOA) & $(0.0926)$ & $(0.1128)$ \\
SIZE & $20.12 \%$ & $19.75 \%$ \\
& $0.0285^{* * *}$ & $0.0428^{* * *}$ \\
PROF & $(0.0062)$ & $(0.0096)$ \\
& $-0.0635^{* * *}$ & $-0.0692^{* * *}$ \\
VOL & $(0.0155)$ & $(0.0189)$ \\
& $-0.0528^{* * *}$ & $-0.0635^{* * *}$ \\
MTB & $(0.0122)$ & $(0.0135)$ \\
& -0.0825 & -0.1125 \\
TANG & $(0.1428)$ & $(0.1624)$ \\
& $0.1452^{* * *}$ & $0.1624^{* * *}$ \\
INDL & $(0.0486)$ & $(0.0536)$ \\
& $0.3062^{* * *}$ & $0.3825^{* * *}$ \\
\hline Time Dummies & $(0.0625)$ & $(0.0938)$ \\
Industry Dummies & Yes & Yes \\
Adjusted ${ }^{2}$ & Yes & Yes \\
\hline
\end{tabular}

Notes: ***,** and * indicate significance at the $1 \%, 5 \%$ and $10 \%$ level respectively. Source: Author's own

Based on the estimation results reported in Table 3, it can be observed that all regressors are stationary at I (0) which means that the nulls for unit root are rejected. However, further analysis based on the dynamic regime switching model can be applied to estimate the rate of adjustment to optimal levels. The target leverage regressions are then reported in Table 4 below for book and market leverage whilst controlling for firm specific characteristics.
Consistent with our expectations, column 1 indicates that rate of adjustment for Malaysian firms are indicatively slower than findings reported in developed markets given that transaction costs are known to be high (Ebrahim, 2014). 


\subsection{Discloser versus non-discloser}

The main results from the regressing equation (7) is reported in Table 5 below. Column 1 reports the results for book leverage whilst column 2 provides results for market leverage. For the sake of brevity, the firm specific determinants (control variables) are not reported.

Regressions control for firm and year fixed effects which accounts for heterogeneity across firms and which is unobservable. Table 5 reports coefficients whilst robust standard errors are reported in parenthesis (White, 1980). The rate of adjustment is distinguished between discloser and non-discloser by using a Wald-test for differences based on the coefficients estimated on the lagged leverage variable $\left(\alpha \_1\right.$ and $\left.\alpha \_2\right)$. The results indicate that discloser firms are able to adjust to optimal levels at more rapid rates relative to the non-discloser group. The difference indicates that the distinction is economically as well as statistically significant. This holds for both measures, book and market leverage. Thus, it is evident that discloser firms tend to face lower adjustment costs given that investors attach a lower risk premium arising from increased voluntary disclosures in a market characterised by high transaction costs and access to financing are based on relationships.

\subsection{Endogenous factors: Financing Imbalance and Growth Opportunities}

The results could arise due to the firms' financing imbalance which could result from deficits or surpluses in cash flow which in turn lead firms to change their financing mix. This is due to potentially lower adjustment costs as a result of it being 'shared' with transaction costs (Faulkender et al., 2012). Thus, these firms are expected to adjust at more rapid rates. In addition, the sign of the financial imbalance (deficit or surplus) is also expected to impact the speed of adjustment to target levels (Dang and Garrett, 2015). Firms with a financing deficit would be given the opportunity to raise capital in order to reach target levels by issuing debt, equity or a mixture of both given the pressure to meet their cash flow demands. In contrast, firms with a surplus would not have similar incentives to alter the financing mix given the absence of pressures to resort to external sources of financing. However, the ability of these firms to reach target levels may be considerably higher given that firms facing deficit may encounter lower costs to retire debt/ repurchase equity relative to firms in surplus when issuing financial securities (Dang et al., 2012). Both situations lead to conflicting predictions and thus are analysed in the current study. The results for financial imbalance are reported in panel A of Table 6 below $^{3}$.

In-line with our empirical predictors we found that firms in deficit adjust at more rapid rates relative to firms with a surplus (Dang and Garrett, 2015). The coefficient of the rate of adjustment indicates that discloser firms adjust at more rapid rates to target levels regardless of financing imbalance (i.e. be it in a deficit or surplus). This provides further validation of our results where such voluntary disclosure allows firms to reach optimal leverage levels at more rapid rates and thus maximise firm value to a greater extent.

In addition to financing imbalance, the current study further considers growth opportunities given that high growth firms would also frequently raise external financing which provides firms with the ability to adjust the composition of capital structure and thus reach optimal levels more easily (Belkhir et al., 2016). Low growth firms in contrast would rely on internal funds, and therefore tend to adjust at slower rates given that the nature of adjustment would be limited by internal cash flows. Panel B reports the results for high growth versus low growth firms. In-line with findings in developed markets, high growth firms are able to adjust at more rapid rates (Dang et al., 2012). The distinction between discloser and non-discloser remains constant where discloser firms tend to adjust at significantly more rapid rates relative to the non-discloser group. Thus, the results are valid regardless of financing imbalance and growth opportunities, both of which necessitate firms to raise external financing and hence provide opportunities and incentives for adjustment to target leverage levels.

3 Financing imbalance is defined as the sum of dividend payment, net investment and changes in working capital minus operating cash flows after interest and taxes (Shyam-Sunder and Myers, 1999). A negative figure indicates a deficit whilst a positive figure indicates surplus firms. 
Table 5: Comparing Speed of Adjustment: Discloser versus non-discloser

\begin{tabular}{|l|c|c|}
\hline & BL & ML \\
\hline Discloser & $0.7528^{* * *}$ & $0.7622^{* * *}$ \\
SOA (\%) & $(0.0825)$ & $(0.0864)$ \\
Non-Discloser & $24.72 \%$ & $23.78 \%$ \\
& $0.8126^{* * *}$ & $0.8306^{* * *}$ \\
SOA (\%) & $(0.0968)$ & $(0.0992)$ \\
Difference SOA (abs.) & $18.74 \%$ & $16.94 \%$ \\
\hline Control Variables & $5.98 \% * * *$ & $6.84 \% * * *$ \\
Time Dummies & Yes & Yes \\
Industry Dummies & Yes & Yes \\
\hline
\end{tabular}

Notes: $* * *, * *$ and $*$ indicate significance at the $1 \%, 5 \%$ and $10 \%$ level respectively. Source: Author's own

Table 6: Endogenous factors: Controlling for financing imbalance and growth opportunities

\begin{tabular}{|c|c|c|c|c|}
\hline & BL & ML & BL & ML \\
\hline \multicolumn{5}{|c|}{ Panel A: Financial Imbalance } \\
\hline & \multicolumn{2}{|c|}{ Deficit Firms } & \multicolumn{2}{|c|}{ Surplus Firms } \\
\hline Discloser & $\begin{array}{c}0.7256^{* * *} \\
(0.0785)\end{array}$ & $\begin{array}{c}0.7303^{* * *} \\
(0.0796)\end{array}$ & $\begin{array}{c}0.7827 * * * \\
(0.0979)\end{array}$ & $\begin{array}{c}0.8025^{* * *} \\
(0.1099)\end{array}$ \\
\hline SOA $(\%)$ & $27.44 \%$ & $26.97 \%$ & $21.73 \%$ & $19.75 \%$ \\
\hline \multirow[t]{2}{*}{ Non-Discloser } & $0.7893 * * *$ & $0.8042 * * *$ & $0.8325^{* * *}$ & $0.8622 * *$ \\
\hline & $(0.1022)$ & $(0.1109)$ & $(0.1244)$ & $(0.1528)$ \\
\hline SOA $(\%)$ & $21.07 \%$ & $19.58 \%$ & $16.75 \%$ & $13.78 \%$ \\
\hline Difference SOA (abs.) & $6.37 \% * * *$ & $7.39 \% * * *$ & $4.98 * * *$ & $5.97 * * *$ \\
\hline \multicolumn{5}{|c|}{ Panel B: Growth Opportunities } \\
\hline & \multicolumn{2}{|c|}{ High Growth Firms } & \multicolumn{2}{|c|}{ Low Growth Firms } \\
\hline Discloser & $\begin{array}{c}0.7388^{* * *} \\
(0.0825)\end{array}$ & $\begin{array}{c}0.7429 * * * \\
(0.0864)\end{array}$ & $\begin{array}{c}0.7805^{* * *} \\
(0.0952)\end{array}$ & $\begin{array}{c}0.8195 * * * \\
(0.1154)\end{array}$ \\
\hline $\mathrm{SOA}(\%)$ & $26.12 \%$ & $25.71 \%$ & $21.95 \%$ & $18.05 \%$ \\
\hline \multirow[t]{2}{*}{ Non-Discloser } & $0.7958 * *$ & $0.8108 * * *$ & $0.8428 * * *$ & $0.8523 * * *$ \\
\hline & $(0.1093)$ & $(0.1162)$ & $(0.1422)$ & $(0.1433)$ \\
\hline SOA $(\%)$ & $20.42 \%$ & $18.92 \% * * *$ & $15.72 \%$ & $14.77 \%$ \\
\hline Difference SOA (abs.) & $5.70 \% * * *$ & $6.79 \% \%^{* * *}$ & $6.23 \% * * *$ & $3.28 \% * *$ \\
\hline Control Variables & Yes & Yes & Yes & Yes \\
\hline Time Dummies & Yes & Yes & Yes & Yes \\
\hline Industry Dummies & Yes & Yes & Yes & Yes \\
\hline
\end{tabular}

Notes: ***,** and * indicate significance at the $1 \%, 5 \%$ and $10 \%$ level respectively. Source: Author's own 


\subsection{Exogenous factors: Accounting for equity versus debt issuers}

The nature of adjustment to target leverage can also be influenced by the security being issued i.e. equity versus debt given that both forms of capital tend to have distinctively differing characteristics. Equity issues are linked to market prices and conditions where managers may be reluctant to issue equities during periods of price suppression and vice-versa (Warusawitharana and Whited, 2015). Debt issues in contrast, are often associated with information asymmetry as well as free cash flows and agency problems (Jensen, 1986; Lewis and Tan, 2016). Thus, in order to evaluate whether equity issuers and debt issuers differ based on the nature of voluntary disclosure, we evaluate the distinction in Table 7. Firms which issue equity in the majority of the years are classified as equity adjusters whilst firms which issue debt in the majority of the years are termed as debt adjusters.

The results indicate that equity issuers tend to adjust at more rapid rates which is in-line with findings in the literature given that bankruptcy costs of exceeding target leverage would weigh-in on adjustment considerations of managers and hence motivate larger equity issues (Drobetz et al., 2015). Despite accounting for the different motivations of debt versus equity issuers, the research found that discloser firms are able to adjust at more rapid rates relative to their non-discloser counterparts. This indicates that managers of discloser firms are able to reduce their adjustment costs via additional voluntary environmental reporting.

In line with previous research, the study reveals that Malaysian firms with voluntary environmental disclosures tend to have lower levels of leverage and opt for greater levels of equities (Ahmad et al., 2003). The results prove to be counter-intuitive given the argument that leverage levels also act as a visibility measure to investors given that borrowings tend to positively affect voluntary disclosure (Fernandez-Feijoo et al., 2014; Baldini et al., 2018). However, given the nature of the empirical model applied, the measure(s) capture the costs of deviating from target leverage and hence the results indicate that firms with such voluntary disclosures tend to favour equity issues. Furthermore, the nature of capital markets in developing countries tends to provide additional incentives for environmental reporting given the attraction to foreign investors which in turn influences costs of equity financing (Ali et al., 2017; Kuzay and Uyar, 2017). The asymmetric findings from segregating firms which are above and below target levels confirms that the results are not spurious and attributable to mechanical mean reversion as suggested in the literature (Chen and Zhao, 2007).

Table 7: Exogenous Factors: Equity issuers versus debt issuers

\begin{tabular}{|l|c|c|c|c|}
\hline & BL & ML & BL & ML \\
\hline \multirow{3}{*}{ Discloser } & \multicolumn{2}{|c|}{ Equity Issuers } & \multicolumn{2}{|c|}{ Debt Issuers } \\
\cline { 2 - 5 } & $0.7325^{* * *}$ & $0.7433^{* * *}$ & $0.7029^{* * *}$ & $0.6825^{* * *}$ \\
SOA (\%) & $(0.0801)$ & $(0.0967)$ & $(0.0695)$ & $(0.0596)$ \\
Non-Discloser & $26.75 \%$ & $25.67 \%$ & $29.71 \%$ & $31.75 \%$ \\
& $0.8044^{* * *}$ & $0.8109^{* * *}$ & $0.7625^{* * *}$ & $0.7235^{* * *}$ \\
SOA (\%) & $(0.1152)$ & $(0.1235)$ & $(0.1036)$ & $(0.0725)$ \\
Difference SOA (abs.) & $19.56 \%$ & $18.91 \%$ & $23.75 \%$ & $27.65 \%$ \\
\hline Control Variables & $7.19 \% * * *$ & $6.76 \% * * *$ & $5.96 \% * * *$ & $4.10^{* * *}$ \\
Time Dummies & Yes & Yes & Yes & Yes \\
Industry Dummies & Yes & Yes & Yes & Yes \\
\hline
\end{tabular}

Notes: $* * *, * *$ and $*$ indicate significance at the $1 \%, 5 \%$ and $10 \%$ level respectively. Source: Author's own 


\section{Conclusions and implications}

The study investigated the rate of adjustment for firms based on the voluntary environmental reporting in the Malaysian capital market. The rationale for selecting Malaysia was based on the nature of the economy which tends to be relationship-based (Ebrahim et al., 2014; Rajan and Zingales, 1998), has the presence of high adjustment costs (Bliss and Gul, 2012; Fraser et al., 2006) as well as a lack of institutional and market pressure to motivate such voluntary disclosure (Ahmed Haji, 2013; Ghazali and Weetman, 2006).

Empirical findings indicate that firms in the discloser category are able to adjust at more rapid rates relative to non-discloser groups. These firms tend to be able to reduce their deviation from target levels which indicates lower adjustment costs often associated with developing markets. The findings from this research indicate that firms are aware of the potential benefit arising from such disclosure which is associated with investors perception and hence influences the corresponding risk premiums. Implications provide an incentive for voluntary environmental reporting which allows maximisation of firm value at levels which are closer to optimal debt levels, this is despite considering financing imbalance as well as growth opportunities.

The empirical results confirm that firms adjust to target levels. The rate of adjustment differs for firms based on the disclosure as well as extent of divergence from optimal levels. Examining firms above target levels, reveals that firms with environmental disclosure are able to adjust at more rapid levels relative to firms without such disclosures. This validates the notion that voluntary disclosure via environmental reporting is aimed to operate at optimal levels and thus maximise firm value. For firms below target levels the research reveals that the absence of such disclosures leads to firms adjusting at more rapid rates indicating that the cost of deviating from target leverage levels are lower for firms with disclosure.

The findings provide an alternative explanation of voluntary disclosure which is motivated by capital structure decisions. In this particular instance, societal pressures for voluntary disclosure enhances firm value which is consistent with the managerial aim of maximising shareholders' wealth. Therefore, the findings provide important insight into understanding managerial motivation in voluntary disclosure which is linked to the reduction in adjustment costs and in turn enhances firm values. Thus, the arguments presented in this study point towards managerial actions which impacts firm value based on societal expectations in the context of a developing country and capital marke

The contributions of the research are two-fold. Firstly, the findings indicate that firms in developing countries such as Malaysia, where political and contracting costs influence the ability to raise external financing, tend to benefit from voluntary environmental reporting. The effect is observed in the ability of above target firms to reach target levels at more rapid rates, whilst allowing firms below target levels to deviate for a longer time, able to correspondingly endure a greater half-life of shocks in borrowings levels. Secondly, the findings indicate the positive impact of voluntary environmental disclosure on maximising firm value. The benefits gained from such voluntary disclosure provides additional risk assessment and management tools for managers to incorporate stakeholders interest whilst ensuring maximisation of shareholders' wealth.

The research however is not without its limitations, with the study limited to a specific country with certain characteristics often associated with developing markets. This was not considered a major limitation as the research specifically wished to investigate the rate of adjustment for firms based on the practice of voluntary environmental reporting in a developing country. That said, for future research, it would be interesting to conduct comparative research among a number of developing countries in ASEAN to observe if similar findings to the ones found in this study are reflected across developing countries. An area of further research would be to include other forms of voluntary disclosures which include governance and social responsibility to evaluate its impact on the rate of adjustment to target leverage which in-turn influences firm value. A further area for future research would be to consider other aspects which could influence a firms' ability to adjust to target levels in order to maximise firm value. These could include present value of bankruptcy costs to opportunity costs of underinvestment as well as the potential for overinvestment. Conducting further research into these areas would provide additional insight and perhaps a more holistic perspective on voluntary environmental disclosures.

\section{Literature}

Abel, A. B. (2018). Optimal debt and profitability in the trade-off theory. Journal of Finance, 73(1), 95-143. https://doi.org/10.1111/jofi.12590

Ahmad, Z., Hassan, S., \& Mohammad, J. (2003). Determinants of Environmental Reporting in Malaysia. International Journal of Business Studies, 11(1), 69-90

Ahmed Haji, A. (2013). Corporate social responsibility disclosures over time: evidence from Malaysia. Managerial Auditing Journal, 28(7), 647-676. https://doi.org/10.1108/MAJ-07-2012-0729.

Akhtaruddin, M., Hossain, M. A., Hossain, M., \& Yao, L. (2009). Corporate governance and voluntary disclosure in corporate annual reports of Malaysian listed firms. Journal of Applied Management Accounting Research, 7(1), 1.

Akhtaruddin, M. (2005). Corporate mandatory disclosure practices in Bangladesh. International Journal of Accounting, 40(4), 399-422. https://doi.org/10.1016/j.intacc.2005.09.007

Ali, W., Frynas, J. G., \& Mahmood, Z. (2017). Determinants of corporate social responsibility (CSR) dis- 
closure in developed and developing countries: A literature review. Corporate Social Responsibility and Environmental Management, 24(4), 273-294. https://doi.org/10.1002/csr.1410

Alrazi, B., De Villiers, C., \& Van Staden, C. J. (2015). A comprehensive literature review on, and the construction of a framework for, environmental legitimacy, accountability and proactivity. Journal of Cleaner Production, 102, 44-57.

https://doi.org/10.1016/j.jclepro.2015.05.022

Andrikopoulos, A., Samitas, A., \& Bekiaris, M. (2014). Corporate social responsibility reporting in financial institutions: Evidence from Euronext. Research in International Business and Finance, 32, 27-35. http://doi.org/10.1016/j.ribaf.2014.02.001

An, Z., Li, D., \& Yu, J. (2015). Firm crash risk, information environment, and speed of leverage adjustment. Journal of Corporate Finance, 31, 132-151. http://doi.org/10.1016/j.jcorpfin.2015.01.015

Aragón-Correa, J. A., Marcus, A., \& Hurtado-Torres, N. (2016). The natural environmental strategies of international firms: old controversies and new evidence on performance and disclosure. Academy of Management Perspectives, 30(1), 24-39.

https://doi.org/10.5465/amp.2014.0043

Arena, C., Bozzolan, S., \& Michelon, G. (2015). Environmental reporting: Transparency to stakeholders or stakeholder manipulation? An analysis of disclosure tone and the role of the board of directors. Corporate Social Responsibility and Environmental Management, 22(6), 346-361. https://doi.org/10.1002/csr.1350

Baldini, M., Dal Maso, L., Liberatore, G., Mazzi, F., \& Terzani, S. (2018). Role of country-and firm-level determinants in environmental, social, and governance disclosure. Journal of Business Ethics, 150(1), 79-98. https://doi.org/10.1007/s10551-016-3139-1

Belal, A. R., Cooper, S. M., \& Roberts, R. W. (2013). Vulnerable and exploitable: The need for organisational accountability and transparency in emerging and less developed economies. Accounting Forum, 37(2), 8191. http://dx.doi.org/10.1016/j.accfor.2013.04.001

Belkhir, M., Maghyereh, A., \& Awartani, B. (2016). Institutions and corporate capital structure in the MENA region. Emerging Markets Review, 26, 99-129. https://doi.org/10.1016/j.ememar.2016.01.001

Bertomeu, J., Beyer, A., \& Dye, R. A. (2011). Capital structure, cost of capital, and voluntary disclosures. Accounting Review, 86(3), 857-886. https://doi.org/10.2308/accr.00000037

Birkey, R. N., Michelon, G., Patten, D. M., \& Sankara, J. (2016). Does assurance on CSR reporting enhance environmental reputation? An examination in the US context. Accounting Forum, 40(3), 143-152. https://doi.org/10.1016/j.accfor.2016.07.001.

Bliss, M. A., \& Gul, F. A. (2012). Political connection and cost of debt: Some Malaysian evidence. Journal of Banking \& Finance, 36(5), 1520-1527. https://doi.org/10.1016/j.jbankfin.2011.12.011
Bond, A., Pope, J., Morrison-Saunders, A., \& Retief, F. (2016). A game theory perspective on environmental assessment: What games are played and what does this tell us about decision making rationality and legitimacy? Environmental Impact Assessment Review, 57, 187-194. https://doi.org/10.1016/j.eiar.2016.01.002

Braam, G. J., de Weerd, L. U., Hauck, M., \& Huijbregts, M. A. (2016). Determinants of corporate environmental reporting: The importance of environmental performance and assurance. Journal of Cleaner Production, 129, 724-734.

http://dx.doi.org/10.1016/j.jclepro.2016.03.039

Brammer, S. \& Pavelin, S. (2008). Factors influencing the quality of corporate environmental disclosure. Business Strategy and the Environment, 17, 120-36. https://doi.org/10.1002/bse.506

Brounen, D., De Jong, A., \& Koedijk, K. (2006). Capital structure policies in Europe: Survey evidence. Journal of Banking \& Finance, 30(5), 1409-1442. https://doi.org/10.1016/j.jbankfin.2005.02.010

Chang, Y. K., Chen, Y. L., Chou, R. K., \& Huang, T. H. (2015). Corporate governance, product market competition and dynamic capital structure. International Review of Economics \& Finance, 38, 44-55. https://doi.org/10.1016/j.iref.2014.12.013

Chen, L., \& Zhao, X. (2007). Mechanical mean reversion of leverage ratios. Economics Letters, 95(2), 223-229. https://doi.org/10.1016/j.econlet.2006.10.008

Cho, C. H., Michelon, G., Patten, D. M., \& Roberts, R. W. (2015). CSR disclosure: the more things change...? Accounting, Auditing \& Accountability Journal, 28(1), 14-35. https://doi.org/10.1108/AAAJ-12-2013-1549

Claessens, S., \& Yurtoglu, B. B. (2013). Corporate governance in emerging markets: A survey. Emerging Markets Review, 15, 1-33. https://doi.org/10.2139/ssrn.1988880

Clarkson, P. M., Li, Y., Richardson, G. D., \& Vasvari, F. P. (2008). Revisiting the relation between environmental performance and environmental disclosure: An empirical analysis. Accounting, Organizations and Society, 33(4-5), 303-327. https://doi.org/10.1016/j.aos.2007.05.003

Cook, D. O., \& Tang, T. (2010). Macroeconomic conditions and capital structure adjustment speed. Journal of Corporate Finance, 16(1), 73-87. https://doi.org/10.2139/ssrn.1101664

Dang, V. A., \& Garrett, I. (2015). On corporate capital structure adjustments. Finance Research Letters, 14, 56-63. https://doi.org/10.1016/j.frl.2015.05.016

Dang, V. A., Kim, M., \& Shin, Y. (2012). Asymmetric capital structure adjustments: New evidence from dynamic panel threshold models. Journal of Empirical Finance, 19(4), 465-482. https://doi.org/10.1016/j.jempfin.2012.04.004

DeAngelo, H., \& Roll, R. (2015). How stable are corporate capital structures? Journal of Finance, 70(1), 373-418. https://doi.org/10.1111/jofi.12163

Deegan, C. (2002). Introduction: the legitimising effect 
of social and environmental disclosures-a theoretical foundation. Accounting, Auditing \& Accountability Journal, 15(3), 282-311. https://doi.org/10.1108/09513570210435852

Dickey, D. A., \& Fuller, W. A. (1979). Distribution of the estimators for autoregressive time series with a unit root. Journal of the American Statistical Association, 74(366a), 427-431. https://doi.org/10.2307/2286348

Doshi, A. R., Dowell, G. W., \& Toffel, M. W. (2013). How firms respond to mandatory information disclosure. Strategic Management Journal, 34(10), 1209-1231. https://doi.org/10.1002/smj.2055

Drobetz, W., Schilling, D. C., \& Schröder, H. (2015). Heterogeneity in the speed of capital structure adjustment across countries and over the business cycle. European Financial Management, 21(5), 936-973. https://doi.org/10.1111/eufm.12048

Ebrahim, M. S., Girma, S., Shah, M. E., \& Williams, J. (2014). Dynamic capital structure and political patronage: The case of Malaysia. International Review of Financial Analysis, 31, 117-128.

https://doi.org/10.1016/j.irfa.2013.11.004

Elsas, R., \& Florysiak, D. (2015). Dynamic capital structure adjustment and the impact of fractional dependent variables. Journal of Financial and Quantitative Analysis, 50(5), 1105-1133. https://doi.org/10.1017/S0022109015000496

Elsas, R., \& Florysiak, D. (2011). Heterogeneity in the speed of adjustment toward target leverage. International Review of Finance, 11(2), 181-211. https://doi.org/10.1111/j.1468-2443.2011.01130.x

European University Institute. (2019). Datastream (Thomson Reuters). EUI. https://www.eui.eu/Research/Library/ResearchGuides/Economics/Statistics/DataPortal/datastream (accessed 24 August 2019).

Faulkender, M., Flannery, M. J., Hankins, K. W., \& Smith, J. M (2012). Cash flows and leverage adjustments. Journal of Financial Economics, 103(3), 632-646. https://doi.org/10.1016/j.jfineco.2011.10.013

Fernandes, S. M., Bornia, A. C., \& Nakamura, L. R. (2018). The influence of boards of directors on environmental disclosure. Management Decision, 57(9), 2358-2382. https://doi.org/10.1108/MD-11-2017-1084

Fernandez-Feijoo, B., Romero, S., \& Ruiz, S. (2014). Effect of stakeholders' pressure on transparency of sustainability reports within GRI framework. Journal of Business Ethics, 122(1), 53-63. http://doi.org/10.1007/s10551-013-1748-5

Fisher, G., Kuratko, D. F., Bloodgood, J. M., \& Hornsby, J. S. (2017). Legitimate to whom? The challenge of audience diversity and new venture legitimacy. Journal of Business Venturing, 32(1), 52-71. http://dx.doi.org/10.1016/j.busvent.2016.10.005

Flannery, M. J., \& Hankins, K. W. (2013). Estimating dynamic panel models in corporate finance. Journal of Corporate Finance, 19, 1-19.

http://dx.doi.org/10/1016/j.corpfin.2012.09.004

Fraser, D. R., Zhang, H., \& Derashid, C. (2006). Capital structure and political patronage: The case of Malaysia. Journal of Banking \& Finance, 30(4), 1291-1308. https://doi.org/10.1016/j.jbankfin.2005.05.008

Ghazali, N. A. M., \& Weetman, P. (2006). Perpetuating traditional influences: Voluntary disclosure in Malaysia following the economic crisis. Journal of International Accounting, Auditing and Taxation, 15(2), 226-248. https://doi.org/10.1016/j.intaccaudtax.2006.08.001

Gorondutse, A. H., Ali, R. A., Abubakar, A., \& Naalah, M. N. I. (2017). The effect of working capital management on SMEs profitability in Malaysia. Polish Journal of Management Studies, 16(2), 99-109. http://doi.org/10.17512/pjms.2017.16.2.09

Hackbarth, D., Miao, J., \& Morellec, E. (2006). Capital structure, credit risk, and macroeconomic conditions. Journal of Financial Economics, 82(3), 519-550. http://doi.org/10.1016/j.fineco.2005.10.003

Halling, M., Yu, J., \& Zechner, J. (2016). Leverage dynamics over the business cycle. Journal of Financial Economics, 122(1), 21-41. http://DOI.org/10.1016/j.jfineco.2016.07.001

Hussain, H.I., Ali, A., Thaker, H.M.T., \& Ali, M. (2019) Firm Performance and Family Related Directors: Empirical Evidence from an Emerging Market, Contemporary Economics, 13 (2), 187 - 204. $\mathrm{http} / / /$ doi.org/10.5709/ce.1897-9254.307

Hussain, H. I., Abidin, I. S. Z., Kamarulzaman, R., \& Shawtari, F. A. (2018). The impact of State Affiliated Directors on the capital structure speed of adjustment in an emerging market. Polish Journal of Management Studies, 18(1), 133-148. http://doi.org/10.17512/pjms.2018.18.1.11

Im, K. S., Pesaran, M. H., \& Shin, Y. (2003). Testing for unit roots in heterogeneous panels. Journal of Econometrics, 115(1), 53-74. https://doi.org/10.1016/S0304-4076(03)00092-7

Jensen, M. C. (1986). Agency costs of free cash flow, corporate finance, and takeovers. American Economic Review, 76(2), 323-329. http://www.jstor.org/stable/1818789

Jose, A., \& Lee, S. M. (2007). Environmental reporting of global corporations: A content analysis based on website disclosures. Journal of Business Ethics, 72(4), 307-321. http://doi.org/10.1007/s10551-006-9172-8

Ju, N., Parrino, R., Poteshman, A. M., \& Weisbach, M. S. (2005). Horses and rabbits? Trade-off theory and optimal capital structure. Journal of Financial and Quantitative analysis, 40(2), 259-281. https://doi.org/10.1017/S0022109000002301

Kareem, M. A., \& Mijbas, H. A. (2019). Mediating Role of Dynamic Capabilities on the Relationship between Human Resource Development and Organizational Effectiveness. Organizacija, 52(3), $187-203$. https://doi.org/10.2478/orga-2019-0012

Khlif, H., Guidara, A., \& Souissi, M. (2015). Corporate social and environmental disclosure and corporate performance: evidence from South Africa and Morocco. Journal of Accounting in Emerging Economies, 5(1), 
51-69. https://doi.org/10.1108/JAEE-06-2012-0024

Kuo, L., \& Yi-Ju Chen, V. (2013). Is environmental disclosure an effective strategy on establishment of environmental legitimacy for organization? Management Decision, 51(7), 1462-1487.

http://dx.doi.org/10.1108/md-06-2012-0395

Kuzey, C., \& Uyar, A. (2017). Determinants of sustainability reporting and its impact on firm value: Evidence from the emerging market of Turkey. Journal of Cleaner Production, 143, 27-39.

http://doi.org/10.1016/j.jclepro.2016.12.153

La Porta, R., Lopez-de-Silanes, F., Shleifer, A., \& Vishny, R. (2000). Investor protection and corporate governance. Journal of Financial Economics, 58(1-2), 3-27. https://doi.org/10.2139/ssrn.183908

Lemma, T., \& Negash, M. (2014). Determinants of the adjustment speed of capital structure: Evidence from developing economies. Journal of Applied Accounting Research, 15(1), 64-99.

https://doi.org/10.1108/JAAR-03-2012-0023

Lewis, B. W., Walls, J. L., \& Dowell, G. W. (2014). Difference in degrees: CEO characteristics and firm environmental disclosure. Strategic Management Journal, 35(5), 712-722. https://doi.org/10.1002/smj.2127

Lemmon, M. L., \& Lins, K. V. (2003). Ownership structure, corporate governance, and firm value: Evidence from the East Asian financial crisis. Journal of Finance, 58(4), 1445-1468.

https://doi.org/10.1111/1540-6261.00573

Levin, A., Lin, C. F., \& Chu, C. S. J. (2002). Unit root tests in panel data: asymptotic and finite-sample properties. Journal of Econometrics, 108(1), 1-24. https://doi.org/10.1016/S0304-4076(01)00098-7

Lewis, C. M., \& Tan, Y. (2016). Debt-equity choices, R\&D investment and market timing. Journal of Financial Economics, 119(3), 599-610.

https://doi.org/10.1016/j.jfineco.2016.01.017

Loudermilk, M. S. (2007). Estimation of fractional dependent variables in dynamic panel data models with an application to firm dividend policy. Journal of Business \& Economic Statistics, 25(4), 462-472. https://doi.org/10.1198/073500107000000098

Mallisa, M., \& Kusuma, H. (2017). Capital structure determinants and firms' performance: empirical evidence from Thailand, Indonesia and Malaysia. Polish Journal of Management Studies, 16(1), 154-164. https://doi.org/10.17512/pjms.2017.16.1.13

Martin-Ortega, J., Brouwer, R., \& Aiking, H. (2011). Application of a value-based equivalency method to assess environmental damage compensation under the European Environmental Liability Directive. Journal of Environmental Management, 92(6), 1461-1470. https://doi.org/10.1016/j.jenvman.2010.12.001

Md Zaini, S., Samkin, G., Sharma, U., \& Davey, H. (2018). Voluntary disclosure in emerging countries: a literature review. Journal of Accounting in Emerging Economies, 8(1), 29-65. https://doi.org/10.1108/JAEE-08-2016-0069
Michelon, G., Pilonato, S., \& Ricceri, F. (2015). CSR reporting practices and the quality of disclosure: An empirical analysis. Critical Perspectives on Accounting, 33, 59-78. http://doi.org/10.1016/j.cpa.2014.10.003

Modigliani, F., \& Miller, M. H. (1963). Corporate income taxes and the cost of capital: a correction. American Economic Review, 53(3), 433-443. http://www.jstor.org/stable/1809167

Modigliani, F., \& Miller, M. H. (1958). The Cost of Capital, Corporation Finance and the Theory of Investment. American Economic Review, 48(3), 261-297. http://www.jstor.org/stable/1809766

Nor, F. M., Ibrahim, K., Haron, R., Ibrahim, I., \& Alias, M. A. (2012). Practices of capital structure decisions: Malaysia survey evidence. International Review of Business Research Papers, 8(1), 33-63.

Öztekin, Ö. (2015). Capital structure decisions around the world: which factors are reliably important? Journal of Financial and Quantitative Analysis, 50(3), 301-323. https://doi.org/10.1017/S0022109014000660

Öztekin, Ö. \& Flannery, M. J. (2012). Institutional determinants of capital structure adjustment speeds. Journal of Financial Economics, 103(1), 88-112. https://doi.org/10.1016/j.jfineco.2011.08.014

Plumlee, M., Brown, D., Hayes, R. M., \& Marshall, R. S. (2015). Voluntary environmental disclosure quality and firm value: Further evidence. Journal of Accounting and Public Policy, 34(4), 336-361.

http://dx.doi.org/10.1016/j.jaccpubpol.2015.04.004

Qian, W., \& Schaltegger, S. (2017). Revisiting carbon disclosure and performance: Legitimacy and management views. British Accounting Review, 49(4), 365-379. https://doi.org/10.1016/j.bar.2017.05.005

Rajan, R. G., \& Zingales, L. (1998). Which capitalism? Lessons from the East Asian crisis. Journal of Applied Corporate Finance, 11(3), 40-48.

https://doi.org/10.1111/j.1745-6622.1998.tb00501.x

Song, J., Wang, R., \& Cavusgil, S. T. (2015). State ownership and market orientation in China's public firms: An agency theory perspective. International Business Review, 24(4), 690-699.

https://doi.org/10.1016/j.ibusrev.2014.12.003

Shyam-Sunder, L., \& Myers, S. C. (1999). Testing static tradeoff against pecking order models of capital structure. Journal of Financial Economics, 51(2), 219-244. http://doi.org/10.1016/s0304-405x(98)00051-8

Ting, I. W. K. (2016). Estimating dynamic panel model of leverage decision: Evidence from Malaysia. Procedia Economics and Finance, 35, 267-273. http://doi.org/10.1016/S2212-5671(16)00033-2

Warr, R. S., Elliott, W. B., Koëter-Kant, J., \& Öztekin, Ö. (2012). Equity mispricing and leverage adjustment costs. Journal of Financial and Quantitative Analysis, 47(3), 589-616. https://doi.org/10.1017/S0022109012000051

Warusawitharana, M., \& Whited, T. M. (2015). Equity market misvaluation, financing, and investment. The Review of Financial Studies, 29(3), 603-654. 
https://doi.org/10.1093/rfs/hhv066

White, H. (1980). A heteroskedasticity-consistent covariance matrix estimator and a direct test for heteroskedasticity. Econometrica, 48(4), 817-838. https://doi.org/10.2307/1912934

Xiao, J. Z., Gao, S. S., Heravi, S., \& Cheung, Y. C. (2005). The impact of social and economic development on corporate social and environmental disclosure in Hong Kong and the UK. Advances in International Accounting, 18, 219-243. http://doi.org/10.1016/S0897-3660(05)18011-8

Yang, S., He, F., Zhu, Q., \& Li, S. (2018). How does corporate social responsibility change capital structure? Asia-Pacific Journal of Accounting and Economics, 25(3-4), 352-387. https://doi.org/10.1080/16081625.2017.1354710

Zhou, Q., Tan, K. J. K., Faff, R., \& Zhu, Y. (2016). Deviation from target capital structure, cost of equity and speed of adjustment. Journal of Corporate Finance, 39, 99-120. https://doi.org/10.1016/j.jcorpfin.2016.06.00

Hafezali Iqbal Hussain, is an Associate Professor at Taylor's Business School, Malaysia. He received his Ph.D. in Finance from the University of Hull, UK. Formerly a chartered accountant at Citigroup, his work has appeared in several peer-reviewed finance, management, education and scientific journals and has presented at various conferences.
Sebastian Kot, is currently Professor in management and supply chain management in the Faculty of Management, Czestochowa University of Technology. $\mathrm{He}$ has over 20 years of teaching, research and managerial experience in higher education. $\mathrm{He}$ is the Extraordinary Professor in the Faculty of Economic and Management Sciences, North-West University, South Africa. He is a Founder and Co-editor of Polish Journal of Management Studies. He is a member of scientific boards of numerous journals as well as the reviewers.

Hassanudin Mohd Thas Thaker, is a lecturer in the Department of Economics and Finance, Sunway University, Malaysia. He holds a PhD in Business Administration (Finance) from International Islamic University (IIUM). His research interest includes international trade, balance of payment, econometrics, corporate finance, Islamic banking and finance, financial economics and housing/properties market.

Jason J Turner, is the Head of the Graduate School of Business, Asia Pacific University of Technology \& Innovation, Malaysia. As an academic for over 17 years he has held and holds a number of external positions, editorial roles and grants. His research is in the area of human capital, investigating the graduate skills gap and preparing learners for the employment market within the context of Industry 4.0, research which has resulted in several peer-reviewed publications. 